\begin{tabular}{lrr}
\hline Volume 22 & Nomor 1, Januari 2021 & Halaman 57—67 \\
URL: https://jurnal.unej.ac.id/index.php/SEMIOTIKA/index & E-ISSN: 2599-3429 & P-ISSN: 1411-5948 \\
\hline
\end{tabular}

\title{
PENGARUH PERCAKAPAN NEGATIF KELUARGA TERHADAP PEMEROLEHAN BAHASA ANAK USIA 3-4 TAHUN
}

\author{
THE INFLUENCE OF NEGATIVE FAMILY CONVERSATION \\ TO LANGUAGE ACQUISITION OF CHILDREN 3-4 YEARS OLD
}

\author{
Imron Maulana* \\ UIN Syarif Hidayatullah Jakarta \\ *Corresponding Author: Imron.maulana18@mhs.uinjkt.ac.id \\ Informasi Artikel: \\ Dikirim: 15/12/2020; Direvisi: 28/12/2020; Diterima: 11/1/ 2021
}

\begin{abstract}
The effect of negative conversation occurs intensively in children aged 3-4 years because it is a period of imitation. This period is one of the stages of socialization that a child gets within his family's scope. This study aims to comprehensively examine the negative conversations that affect language acquisition, especially phonological acquisition, mainly acquiring vowels that occur in SM and NS. The research method used is a qualitative descriptive method. The study results revealed that negative conversation significantly affected children's language acquisition and its characteristics. The concrete reality at this stage, especially when the family says anything, then gradually the child brain area will process it. The child will repeat it. This phenomenon occurs repeatedly, and then it is not imagined that he will speak these words spontaneously. A child tends to say it without understanding the meaning. Still, it will affect his character if the negative sentences internalized to his thought. Adopting this negative conversation tends to have unideal characteristics because a child does not imitate his negative words. Still, he tries to understand the meaning uttered by the person closest to him. In this case, the study results reveal that negative conversations significantly affect children's language acquisition and affect their characteristics. The conclusion is that language acquisition through an unfavourable exchange is obtained by internal (family) factors and external factors.
\end{abstract}

Keywords: harsh Sundanese language, imitation, language acquisition, negative conversation

Abstrak
Pengaruh percakapan negatif terjadi secara intensif pada anak yang berusia 3-4 tahun
karena pada fase tersebut diasosiasikan dengan masa peniruan (imitasi). Masa tersebut
merupakan salah satu tahap sosialisasi yang diperoleh seorang anak dalam lingkup
keluarganya. Tujuan penelitian ini adalah untuk mengkaji secara komprehensif perihal
percakapan negatif yang berpengaruh pada pemerolehan bahasa, khususnya pemerolehan
secara fonologis, yakni pemerolehan vokal yang terjadi pada SM dan NS. Adapun metode
penelitian yang digunakan, yakni metode deskriptif kualitatif. Hasil penelitian
mengungkapkan bahwa percakapan negatif berpengaruh besar terhadap pemerolehan
bahasa anak dan karakteristiknya. Realitas konkret pada anak, yakni ketika keluarga
mengucapkan sesuatu hal, maka secara bertahap pada area otak akan mengolahnya,
sehingga akan diucapkan kembali oleh anak tersebut. Fenomena ini terjadi secara berulang
sehingga ia akan mengucapkan kata-kata tersebut secara spontanitas. Pada hakikatnya, ia 
hanya sekadar mengucapkan saja, tetapi jika hal tersebut sudah terinternalisasi dalam dirinya, maka akan berdampak pada kepribadian. Dengan mengadopsi dari percakapan tersebut, ia akan cenderung memiliki karakteristik yang tidak ideal karena sang anak tidak hanya menirukan kata-kata negatifnya saja, melainkan ia berusaha untuk memahami makna yang diucapkan oleh orang terdekatnya tersebut. Kesimpulannya adalah pemerolehan bahasa melalui percakapan negatif tidak hanya didapatkan oleh faktor internal (keluarga), tetapi pun faktor eksternal.

Kata kunci: bahasa Sunda kasar, peniruan, pemerolehan bahasa, percakapan negatif

\section{PENDAHULUAN}

Manusia adalah makhluk sosial yang tidak bisa hidup sendiri, melainkan selalu membutuhkan peran orang lain, khususnya dalam bersosialisasi. Hal itu dikarenakan manusia saling membutuhkan satu sama lain. Purba (2005:11) mengungkapkan bahwa sebagai makhluk sosial, manusia tidak bisa hidup seorang diri, melainkan di mana pun dan bila apa pun, seorang individu senantiasa membutuhkan kerja sama dengan sesamanya. Pembentukan kelompok sosial antara sesama adalah representasi konkret untuk mempertahankan hidup dan mengembangkan kehidupan manusia. Dalam menjalin kehidupan sosial manusia akan cenderung melakukan interaksi sosial yang out put-nya untuk menghasilkan ketertiban sosial. Suatu keniscayaan bahwa dari interaksi tersebut akan menghasilkan sesuatu yang bermakna, seperti terjalinnya keluarga inti, keluarga secara luas atau dapat dikatakan lingkup eksternal, dan yang paling urgensi adalah membentuk kelompok sosial. Ketika berbicara mengenai keluarga inti erat kaitannya dengan sosialisasi primer yang didapatkan oleh seorang anak dalam memahami nilai dan norma yang terinternalisasi pada lingkungan pertamanya.

Adapun menurut George Herbert Mead (dalam Waluja, 2007:67-68), sosialisasi yang dilalui seseorang melalui tahap-tahap berikut ini.

Tahap persiapan atau dalam istilah sosiologi dikenal dengan (prepatory stage). Sejak manusia terlahir kedua dan tumbuh dengan perkembangannya, maka ia akan berusaha untuk mengenali dirinya. Dalam tahap ini, benang merah yang difokuskan bahwa seorang anak mengalami proses peniruan (imitasi) yang ada di sekelilingnya, tetapi belum sempurna. Contohnya: ketika ia menirukan kata "makan", tetapi yang diucapkannya menjadi "mam". Hal tersebut secara sosiologis membuktikan bahwa usia merupakan salah satu faktor yang memengaruhinya, yaitu dalam hal pengucapan yang belum sempurna. Hal ini terjadi pada anak usia 1-2 tahun.

Tahap meniru (play stage). Dalam tahap ini, seorang anak mulai menirukan sesuatu dan peniruan tersebut terjadi dengan intensif, sehingga ia mulai terbentuk pemahaman mengenai hal-hal yang berada di sekelilingnya dengan semakin sempurna. Karena memang peran keluarga begitu intensif terjadi, seorang anak sudah bisa mengetahui siapa orang tuanya, kakak, dan lain-lain. Dalam fase ini seorang anak sudah mulai menempatkan diri pada posisi orang lain. Contohnya: ketika Marsha melihat ibunya sedang menimang-nimang bayi, ia seolah-olah menirukan gaya dan perannya tersebut menjadi seorang ibu.

Tahap siap bertindak (game stage). Pada tahap ini, proses peniruan sudah mulai berkurang dan digantikan oleh peran langsung yang menempatkan diri seorang anak dengan penuh kesadaran. Salah satu karakteristiknya, yakni sang anak sudah mengenali norma-norma 
yaang tidak hanya terinternalisasi dalam keluarganya saja, melainkan norma dalam masyarakat sudah dipahami dengan intensif. Contohnya: seorang anak yang sudah bisa merepresentasikan perilaku sopan santun ketika bertemu dengan orang tua.

Tahap penerimaan norma kolektif (generalized other). Pada tahap ini seorang anak sudah mengalami fase dewasa dan ia bisa menempatkan posisinya di masyarakat atau dengan kata lain seorang individu sudah menjadi bagian dari warga masyarakat secara sepenuhnya. Prinsip kerja sama dan sikap toleransi sudah terinternalisasi dengan intensif. Contohnya: Andi yang melakukan kegiatan gotong royong bersama teman-temannya di kampung halaman.

Dalam artikel ini peneliti lebih memfokuskan pada satu tahap sosialisasi saja, yakni play stage. Subjek penelitian adalah dua orang anak yang berada dalam fase peniruan intensif. Menurut Nuryani dan Putra (2013:88) dalam perspektif psikolinguistik terdapat tiga hal pokok yang urgensi, yakni (1) proses mental tertentu yang dialami oleh seseorang dalam mendengar, memahami, dan mengingat sesuatu yang didengarnya (comprehension); (2) proses mental yang terjadi ketika seseorang mengungkapkan sesuatu yang dikatakannya (production); adapun (3) prosedur yang diikuti anak-anak dalam belajar memahami atau memproduksi bahasa pertamanya (acquisition). Berkaitan dengan hal tersebut, tampaknya akan diasosiasikan dengan pemerolehan bahasa sesuai dengan tahapan perkembangan usia anak, yakni peniruan, pemahaman terhadap makna, dan penggunaan mengenai kata-kata dalam komunikasi.

Berbicara mengenai hipotesis, dalam hal ini peneliti menggunakan hipotesis tabularasa sebagai kajian analisis pemerolehan bahasa. Hipotesis tabularasa dikorelasikan dengan suatu istilah 'kertas kosong' yang memiliki makna belum 'tertulis' apa pun. Artinya, bahwa otak seseorang ketika dilahirkan itu seperti kertas kosong dan tulisan-tulisan lah yang akan mengisinya, yakni berhubungan dengan pengalaman hidup seseorang. Hal tersebut memberikan suatu pemahaman bahwa proses pemerolehan bahasa dipengaruhi oleh masukan dari lingkungan eksternalnya. Proses pemerolehan bahasa anak secara konkret menitikberatkan pada pengamatan akan peristiwa-peristiwa linguistik/kebahasaannya.

Dalam hal ini, percakapan negatif yang akan dikaji adalah penggunaan bahasa Sunda. Bahasa Sunda digunakan oleh sebagian besar penduduk di Jawa Barat, kecuali di daerah Cirebon, Indramayu, dan di bagian utara daerah Banten yang notabenenya menggunakan campuran yakni bahasa Sunda dan Jawa. Penelitian ini mengambil objek penggunaan bahasa Sunda daerah Bogor. Di daerah pedesaan, bahasa Sunda dijadikan sebagai bahasa pengantar untuk berkomunikasi dengan sesama. Dalam hal kehalusan bahasa sering dikemukakan bahwa bahasa Sunda yang masih murni dan halus terdapat di daerah Priangan, yaitu di Kabupaten Ciamis, Tasikmalaya, Garut, Bandung, Sumedang, Sukabumi, dan Cianjur. Bahkan, terdapat suatu asumsi bahwa bahasa Cianjur merupakan bahasa Sunda terhalus. Kabupaten Bogor adalah suatu daerah yang mayoritas masyarakatnya dalam interaksi sosial memakai bahasa Sunda, tetapi dalam suatu observasi daerah Bogor tidak termasuk ke dalam bahasa Sunda yang murni ataupun halus. Oleh karena itu, peneliti akan menjadikan bahasa Sunda kasar (Bogor) sebagai bagian dari objek penelitian ini.

Adapun tujuan penelitian ini adalah untuk mengetahui proses pemerolehan bahasa seorang anak yang berusia 3 dan 4 tahun melalui percakapan negatif dari keluarganya. Adapun percakapan tersebut salah satunya akan berpengaruh terhadap pemerolehan vokal yang 
didapatkan oleh seorang anak. Hal tersebut menurut peneliti memiliki urgensi permasalahan yang konkret, sebab seseorang dapat mengetahui bahwa ternyata percakapan negatif akan berpengaruh besar terhadap pemerolehan bahasa anak.

Hasil-hasil riset sebelumnya yang berhubungan dengan penelitian ini adalah terdapat pada observasi yang dilakukan oleh Oktavian Aditya Nugraha dengan judulnya, yakni "Pemerolehan Bahasa Anak Usia 4 Tahun Kajian Semantik Penyimpangan Tuturan Anak". Secara general dalam penelitian ini memaparkan perihal suatu proses penyimpangan tuturan yang diakibatkan oleh dua faktor yang sangat mempengaruhinya, yakni faktor fisiologis dan psikologis. Adapun faktor fisiologis dapat dikorelasikan dengan organ-organ yaang menghasilkan tuturannya, sedangkan faktor psikologis berkenaan dengan perkembangan pengetahuan (kognitif) seorang anak dalam memperoleh bahasa pertamanya. Adapun penelitian selanjutnya dilakukan oleh Prima Gusti Yanti dengan judul penelitian "Pemerolehan Bahasa Anak: Kajian aspek Fonologi Pada Anak Usia 2-2,5 Tahun”. Dalam penelitian ini lebih menitikberatkan pemerolehan bahasa dari aspek fonologi, baik itu pemerolehan konsonan, dan faktor-faktor yang memengaruhinya.

\section{METODE}

Metode penelitian ini adalah deskriptif kualitatif dengan pendekatan studi kasus dalam analisisnya. Untuk setiap fenomena akan dikaji secara mendetail berupa deskripsi secara komprehensif. Bahan analisis penelitian berupa pemerolehan bahasa anak usia 3-4 tahun yang dipengaruhi oleh percakapan negatif keluarga dan lingkungan eksternalnya.

Adapun sumber data dalam penelitian ini adalah dua orang anak SM dan NS pada usia 3 dan 4 tahun dan sumber data pendukung, yakni orang-orang terdekat SM dan NS baik itu keluarga dan tetangganya yang berbahasa Sunda kasar. Data tersebut diperoleh melalui observasi partisipan yang dilakukan peneliti. Anak SM dan NS hidup dalam lingkungan masyarakat Sunda, yakni di daerah Ciseeng (Bogor). Proses pemerolehan bahasa pertamanya dipengaruhi oleh percakapan negatif dalam bahasa Sunda. Selama penelitian, peneliti berada satu rumah dengan SM dan NS, sehingga memahamai proses pemerolehan bahasa, khususnya yang terkait dengan percakapan negatif keluarga dan lingkungan sekitarnya.

Dalam pemilihan sampel peneliti terlebih dahalu memahami fase perkembangan bahasa anak, pun dengan mengaitkannya secara sosiologis mengenai tahapan-tahapan sosialisasi. Setelah mengetahui hal tersebut, peneliti mengklasifikasikan pemerolehan bahasa berdasarkan klasifikasi usia. Pengumpulan data dengan menggunakan teknik simak dengan menitikberatkan pada penyimakan percakapan dalam suatu keluarga, sehingga percakapan yang teridentifikasi adalah suatu pembicaraan dengan mengungkapkan kata-kata yang negatif. Teknik simak dibagi menjadi dua, yaitu Simak Libat Cakap (SLC) dan Simak Bebas Libat Cakap (SBLC) (Sudaryanto, 1993:133-134). Dalam hal ini, teknik yang digunakan oleh peneliti adalah SLC. Hal itu disebabkan karena teknik tersebut lebih menitikberatkan pada teknik observasi pengamatan langsung.

Secara sosiologis, ketika seseorang ingin melakukan penelitian maka terdapat dua macam cara, yakni observasi partisipan dan observasi nonpartisipan. Perbedaan tersebut lebih memfokuskan kehadiran seorang peneliti dalam melakukan observasinya. Amirul dan 
Hariyono (2007:115) menyatakan bahwa terdapat dua macam metode pengumpulan data, yakni observasi partisipan dan observasi nonpartisipan. Observasi partisipan akan cenderung dikorelasikan dengan suatu proses pengamatan yang dilakukan oleh peneliti (observer) melalui keikutsertaan secara langsung, sehingga pengamatan akan lebih terlihat konkret. Dalam hal ini, peneliti menggunakan teknik tersebut secara komprehensif.

\section{HASIL DAN PEMBAHASAN}

Pada hakikatnya manusia tidak akan terlepas dengan interaksi sosial. Dalam hal ini, data yang didapatkan melalui percakapan negatif dari suatu keluarga inti, yakni terdiri atas seorang ayah, ibu, dan anak. Pengaruh eksternal (lingkungan sosial), khususnya tentang percakapan negatif turut serta mendukung pemerolehan bahasa anak. Secara umum percakapan yang diutarakan keluarga kepada seorang anak dilakukan dengan tidak sengaja atau dapat dikatakan secara spontanitas. Secara sosiologis kata-kata negatif berpengaruh terhadap kelangsungan hidup seorang anak. Salah satu penyebab mengapa individu mengeluarkan kata-kata negatif dalam percakapan adalah karena emosi yang tidak bisa dikendalikan, tetapi tak hanya itu percakapan negatif dapat terjadi karena lingkungan masyarakat itu sendiri yang sudah terbiasa dan mereka menyepakatinya dalam suatu konvensi.

Percakapan ini dilakukan dengan menggunakan bahasa pertama, yakni bahasa Sunda. Hal itu disebabkan dua faktor. Pertama, karena beberapa keluarga tersebut hidup dalam lingkungan sosial yang berbahasa Sunda, sehingga ketika berinteraksi dengan sesama, dalam lingkup keluarga memakai bahasa pertamanya. Kedua, ketika seseorang sedang mengalami tingkat emosi yang tinggi atau dapat direpresentasikan ke dalam dinamika perasaan, maka secara konkret hal-hal yang berkaitan dengan sesuatu yang pertama kali didapatkan semasa sosialisasi primernya (keluarga) atau dalam ilmu sosiologi disebut sebagai primordialisme, maka dalam hal ini salah satu yang didapatkannya adalah bahasa. Primordialisme dapat dimaknai sebagai sebuah pandangan yang menitikberatkan semua hal-hal yang diperolehnya sejak kecil, baik itu mengenai kepercayaan, tradisi, ataupun segala sesuatu yang terdapat di dalam lingkungan sosial pertamanya, khususnya dalam hal ini bahasa pertamanya.

Dalam hal ini, antara SM dan NS hanya memiliki perbedaan usia 1 tahun saja. Adapun SM berusia 4 tahun, sedangkan NS 3 tahun. Mereka tumbuh sebagaimana mestinya anak-anak, yakni penuh dengan canda tawa dan sangat aktif. Ketika menilik kehidupan sehari-harinya mereka tidak hanya berinteraksi dengan keluarga saja, tetapi juga berkomunikasi dengan orang lain, baik itu tetangga maupun teman-teman yang memiliki kesamaan usia dengannya. Dari hal tersebut, terlihat nyata bahwa proses pemerolehan bahasanya sangat beragam, tetapi dalam hal ini yang lebih difokuskan adalah percakapan negatifnya.

Berikut ini akan dipaparkan data, yakni sebuah penggalan percakapan yang diperoleh dari suatu keluarga, yakni untuk menganalisis percakapan negatif yang berpegaruh terhadap pemerolehan bahasa anak usia 3-4 tahun. Berdasarkan pemaparan sebelumnya bahwa data-data ini diperoleh dari percakapan yang menggunakan bahasa Sunda kasar yang berada di daerah Bogor.

RM: "Kamana bae, ai sia, eweh gawena pisan!" (perintah RM).

AM: (Sekejap terdiam) dan menjawab "Aing karak geh tos dititah ku umi." 
Menilik hal itu, jika diterjemahkan dalam bahasa Indonesia, RM mengucapkan kalimat yang memiliki makna, yaitu "Darimana saja kamu, tidak ada kerjanya sama sekali!, sedangkan AM menjawabnya dengan mengimplisitkan makna "Saya baru saja diperintah oleh ibu". Dari percakapan tersebut terdapat dua bunyi secara fonologis , yakni [sia] dan [aing]. Dalam bahasa Sunda kasar seperti di Bogor, pengucapan [sia] adalah untuk menunjukkan sesuatu terhadap orang lain atau dapat diasosiasikan dengan makna [kamu]. Dalam realitas masyarakat Sunda, jika pengucapan kata tersebut dilakukan oleh seorang anak yang masih di bawah umur, yakni dalam hal ini berusia 3-4 tahun, maka terdapat kesalahan dalam suatu keluarga karena ia tidak memahami konteks tuturan. Yang seharusnya pengucapan kata [sia] tidak sewajarnya jika diucapkan oleh anak usia tersebut. Hal itu disebabkan karena terkesan telah melanggar norma kesopanan dalam melakukan komunikasi.

Dari hal tersebut, percakapan yang dilakukan oleh kaka beradik, yakni MR dan AM telah memberikan pengaruh negatif untuk pemerolehan bahasa secara fonologis, yakni pengucapan kata [sia]. Jika menilik unsur suprasegmental dalam linguistik, kata tersebut cenderung diucapkan dengan memiliki tekanan yang tinggi atau dapat direpresentasikan mengucapkannya dengan konteks nada sedang marah. Unsur suprasegmental lebih menitikberatkan unsur bahasa yang posisi kehadirannya bergantung proses tuturan utu diungkapkan. Peneliti menyimak percakapan MR dan AM dengan memperhatikan konteksnya.

Adapun ketika intensitas percakapan itu sering terjadi, khususnya pengucapan kata [sia], SM menyimak dan mendengarkannya berulang kali, maka tak khayal ketika dalam hal ini SM sedang kesal atau pun marah, maka ia selalu mengucapkan kata [sia] untuk menunjukkan ketidaksukaannya pada orang lain. Tidak hanya pengucapan secara fonologis saja, melainkan SM merepresentasikan kata tersebut dengan konteks nada marah, sebab ia mengalami proses imitasi (peniruan) dari orang terdekatnya tersebut.

Adapun data selanjutnya diperoleh dari percakapan negatif yang diungkapakan oleh SL dan JM. Percakapan tersebut terjadi pada satu lingkup keluarga, dengan tidak dipengaruhi oleh unsur pertengkaran, tetapi karena memang pengucapan kata-kata negatif ini tampaknya sudah biasa diungkapkan, khususnya oleh masyarakat Ciseeng (Bogor).

SL: "Sugan aing naon eta, kaget aing" (terkejut)

JM: "Heeh puguh aing geh da, kaget".

Menilik hal itu, jika diterjemahkan dalam bahasa Indonesia SL mengungkapkan bahwa "Saya kira apa, kaget saya", berbeda dengan SL yang terkejut JM menjawab nya dengan intonasi datar, yakni "Iya saya juga, kaget". Dari percakapan tersebut, peneliti dapat menganalisis bahwa percakapan negatif dapat teridentifikasi pada kata [aing]. Kata tersebut memang pada dasarnya memiliki makna [saya], tetapi jika menilik dalam bahasa Sunda, kata tersebut termasuk ke dalam klasifikasi bahasa yang kasar. Terlebih dalam realitasnya seorang anak, yakni SM belum memahami konteks tututan, misalnya ketika SM mengucapkannya pada orang yang lebih tua, maka secara konkret terkesan tidak sopan. Hal itu disebabkan karena kata [aing] lebih berkonotasi negatif. Selanjutnya, peneliti akan menganalisis pemerolehan huruf vokal melalui percakapan negatif keluarga yang berpengaruh pada pemerolehan bahasa, khususnya dalam hal ini objek yang akan dikaji adalah AM yang berusia 3 tahun. 


\section{Pemerolehan Vokal Melalui Percakapan Negatif}

Pemerolehan vokal (fonologi) dari NS dan SM melalui percakapan negatif orang-orang terdekatnya ataupun kelompok primer nya (keluarga). Tidak hanya itu, percakapan negatif pun dipengaruhi oleh lingkungan eksternalnya. Berdasarkan pengamatan peneliti terdapat bunyibunyi vokal yang muncul secara spontatintas diungkapkan oleh AM dengan proses imitasi (peniruan).

Dalam perkembangan bahasanya, tampaknya bunyi vokal [a] adalah suatu bunyi huruf pertama yang dikuasai oleh AM dan SM, pun dikuasainya secara utuh. Bunyi itu muncul secara jelas dan fasih, tetapi memang terdapat beberapa pengucapan kata yang belum sempurna. Katakata tersebut diungkapkannya baik itu terletak pada bagian awal, tengah, dan akhir. Pemerolehan huruf vokal tersebut diperoleh oleh AM melalui lingkungan luarnya. Tentunya, melalui percakapan negatif yang terjadi begitu intensif. Bunyi vokal [a] pada bagian awal muncul melalui percakapan negatif berikut ini.

MA: "Anjing, kunaon lagian manehna hente ilu kaditu?"

RM: "Sabar, atuh ulah ngotot terus, ai maneh teh!

Pada dialog MA memiliki makna "Anjing, kenapa dia tidak mengikuti ke sana?", sedangkan RM menjawabnya dengan "Sabar, jangan marah terus, kamu!". Menilik hal itu, kata [anjing] tidak diasosiasikan dengan makna denotasi (sebenarnya) yang memang notabenenya berhubungan dengan "binatang mamalia", melainkan kata [anjing] memiliki makna konotasi (makna tidak sebenarnya) dengan sesuatu, yakni nama binatang yang cenderung diucapkan oleh seseorang ketika marah atau pun kesal terhadap situasi dan kondisi tertentu. Dalam hal ini, kata [anjing] tidak hanya terdengar sekali saja, melainkan pengucapannya menjadi terimajinasi dengan intensif oleh AM, sehingga ia menirukan pengucapan tersebut dengan baik. Hal itu disebabkan oleh kata [a]njing terdapat huruf awal berupa vokal [a], maka untuk pengucapannya lebih mudah terepresentasikan oleh AM.

Berikut ini merupakan bunyi vokal [a] di tengah kata terdapat pada percakapan negatif antara LN dan JM. Pembicaraan ini terjadi ketika LN dalam konteks hendak bercanda terhadap JM, tetapi ketika melihat makna percakapan tersebut, ternyata jika dianalisis dan dihubungkan dengan realitas masyarakat Sunda terdapat kata yang bernilai negatif.

LN: "Eh ai maneh calang jasa, hente cape apa?"

JM: "Hente, biasa wae, hente capek"..

Pada pembicaraan yang dilakukan oleh LN memiliki makna, yakni "Eh, kenapa kamu calang jasa?", "Kamu tidak lelah?", sedangkan JM menjawab dengan kalimat "Tidak, biasa saja, tidak lelah". Ketika percakapan tersebut terjadi, AM pun mendengarkannya dengan berulang kali, sehingga secara konkret ia berusaha untuk menirukan kata [calang] tersebut. Perolehan bahasa yang didapatkan oleh AM setelah ditelisik secara fonologis termasuk ke dalam bunyi vokal [a] yang muncul di tengah kata, yakni c[a]lang, karena pengucapannya belum sempurna, maka menjadi [calan]. Hal itu disebabkan karena bunyi [ng] termasuk ke dalam penggabungan huruf konsonan, sehingga direpresentasikan dengan pengucapan yang belum sempurna, terkhusus yang diucapkan oleh anak yang berusia 3 tahun. 
Menilik hal itu, peneliti dapat menganalisis bahwa walaupun percakapan tersebut tidak dalam konteks suasana yang mengimplisitkan nilai negatif, tetapi ungkapan yang dikemukakan oleh LN, yakni terdapat pada kata [calang], setelah peneliti mengetahui maknanya melalui bahasa Sunda yang kasar, maka dapat dihubungkan dengan nilai negatif, yaitu mengacu pada karakteristik kebodohan manusia.

Adapun bunyi vokal [a] yang muncul di bagian akhir terepresentasikan dalam percakapan negatif berikut, yakni terdapat pada kata rad[a]-rad[a]. Dalam hal ini, konteks percakapan yang dilakukan LN dan JM kembali, yakni sedang membahas bahwa perilaku LN dalam bermain cenderung tidak jelas dan membuat kesal JM, sehingga tak khayal di antara kedua nya terjadi pertengakaran. Adapun karena mereka sering bermain di rumah AM, pun kata [rada-rada] memang sudah tak asing lagi di daerah bogor, terkhusus Ciseeng, maka kata tersebut sering kali diucapkan oleh anak-anak kecil, yakni dalam hal ini antara LN dan JM. Akan tetapi, AM pun mendengar pembicaraan tersebut secara intensif, sehingga ia bisa untuk mengucapkan kata [rada-rada] tersebut, walaupun pengucapannya belum sempurna.

LN: "Ih sia te jelas jasa lamun ulin, rada-rada!"

JM: "Sia meren tah anu te jelas!"

Dalam hal ini, dengan proses perkembangan bahasa dari AM, maka untuk pengucakapan kata [rada-rada] diucapkannya belum sempurna hingga menjadi [lada-lada]. Hal itu disebabkan karena AM belum sempurna untuk pengucapan huruf konsonan, yakni [r], sehingga ia merepresentasikannya menjadi huruf [1]. Jika mengkorelasikannya dengan maknanya bahwa kata [rada-rada] dalam bahasa Sunda kasar bermakna negatif, yakni berhubungan dengan kebodohan dan ketidakjelasan seseorang.

Setelah peneliti memaparkan data-data pemerolehan bahasa dari huruf vokal [a] yang berada di bagian awal, tengah, dan akhir, maka selanjutnya akan dikemukakan data-data huruf vokal [i] pun terdapat pada bagian yang sama, yaitu awal, tengah, dan akhir kata. Bunyi vokal [i] muncul pun dilafalkan dengan jelas. Dalam hal ini, bunyi vokal [i] yang terdapat di awal kata terdapat pada penggalan percakapan negatif berikut, yakni pada kata [i]ndomaret.

\section{A: "Lif, sia endek ka indomaret moal!"}

R: "Hente, te boga duit."

Adapun makna dari percakapan tersebut, yakni A mengungkapkan bahwa ia mengajak $\mathrm{R}$ untuk pergi ke [indomaret], tetapi ketika diasosiasikan ke dalam salah satu unsur suprasegmental, yakni "A" mengungkapkan intonasi yang memerintah. Akan tetapi, R menjawabnya dengan intonasi yang biasa saja. Secara fonologis pengucapan kata [i]ndomaret terdapat pada bagian awalan vokal [i], sehingga berkaitan dengan data tersebut. Kata [indomaret] sudah tak asing lagi di telinga masyarakat, sebab makna kata itu dihubungkan dengan suatu tempat yang penuh dengan makanan, sehingga AM dapat mudah mengucapkannya karena dipengaruhi oleh daya imajinasinya.

Untuk pemerolahan vokal dari percakapan negatif, peneliti hanya menganalisis vokal [u] saja yang terletak di bagian tengah kata, yakni ngin[u]m. Adapun vokal $[\mathrm{u}]$ secara fonologis dapat diperoleh melalui percakapan negatif berikut ini. 
I: "Jang, endek nginum"

A: "Heeh Mi, nuhun"

Adapun pemerolehan bahasa dari SM terdapat pada kata [nginum]. Untuk pengucapannya SM sudah terepresentasikan dengan fasih. Hal itu disebabkan salah satunya karena faktor usia. Dalam bahasa Sunda kasar kata [nginum] dikorelasikan ke dalam kosakata, yakni [minum]. Berkaitan dengan hal tersebut, karena kata [nginum] selalu bersentuhan dengan kehidupan sehari-hari, maka suatu hal konkret bahwa dari percakapan tersebut, SM dapat melakukan proses imitasi kata tersebut dengan baik. Mengingat ketika melihat aspek makna kata tersebut mengimplisitkan arti yang sangat jelas, yakni ketika seseorang mengalami kehausan tentunya dengan [minum], terkhusus yang dilakukan oleh anak yang berusia 4 tahun melalui pengucapannya.

Selanjutnya, peneliti akan memaparkan pemerolehan bahasa melalui percakapan negatif terkhusus yang diperoleh oleh SM, yaitu bunyi vokal [e] yang berada di suku terakhir kata, yakni mony[e]t. Bunyi tersebut dilafalkan dengan baik dan intonasi yang jelas.

LN: "Sia, endek jajan moal, monyet, ngalilaken!

JM: "Hayu, kedeng-kedeng atuh, sabar, sia, aing neangan duit hela"

Dari hal tersebut sangat jelas terepresentasikan perihal percakapan negatif yang dilakukan oleh LN dan JM, terkhusus pada kata [monyet]. Dalam KBBI, monyet memiliki makna kera yang bulunya berwarna keabu-abuan dan identik dengan berekor panjang. Akan tetapi, dalam konteks percakapan tersebut mengimplisitkan makna kata dengan tidak mengkorelasikannya pada makna denotasi, tetapi berhubungan dengan makna konotasi, yakni kata [monyet] diungkapkan oleh LN karena ia sedang mengungkapkan kekesalannya kepada JM.

Dalam realitas masyarakat kata [monyet] diidentikkan dengan kata kasar yang secara konkret pengungkapannya disertai intonasi yang tinggi, maka secara tidak langsung konteksnya berkenaan dengan seseorang yang sedang marah. Adapun dinamika emosi selalu terjadi pada manusia. Bagi seseorang yang meluapkan emosinya dengan menggunakan kata-kata kasar seperti yang terjadi pada percakapan antara LN dan JM. Kata [monyet] memang di lingkungan masyarakat Sunda kasar sudah tidak asing lagi, begitupun yang terjadi di lingkungan sosial peneliti bahwa salah satu dampak dari percakapan negatif tersebut, mengakibatkan NS cukup fasih mengucapkannya pun disertai dengan konteks ketika ia marah. Dalam hal ini, penulis hanya mengambil salah satu sampel saja perihal percakapan yang menggunakan kata [monyet]. Untuk selanjutnya, peneliti akan memaparkan percakapan negatif dengan menitikberatkan pada pemerolehan vokal [o] yang berada di akhir kata. Menilik hal itu, berikut ini merupakan percakapan negatif yang dilakukan oleh LN dan JM.

LN: "Dongo amat nya?"

JM: "Tinyaho, tah manehna te jelas".

Dari percakapan tersebut, dapat terepresentasikan secara konkret bahwa pemerolehan vokal [o] terdapat pada akhir kata, yakni dong[o]. Kata tersebut sudah lumrah di telinga masyarakat.Makna kata [dongo] dihubungkan dengan suatu karakteristik seseorang dengan 
kebodohannya. Berdasarkan observasi yang telah dilakukan, khususnya dalam realitas masyarakat Sunda kasar, kata tersebut memang memiliki konotasi yang negatif. Adapun arti pembicaraan yang dikemukakan LN adalah "Bodoh sekali ya?", sedangkan respons JM dengan mengimplisitkan makna "Tidak tahu tuh, dia tidak jelas". Tentunya, dari percsakapan tersebut terdapat makna negatif, yakni terdapat pada kata [dongo], sehingga berdampak pada pemerolehan bahasa NS. Ia mengucapkannya dengan jelas dan fasih. Hal itu disebabkan secara fonologis untuk pengucapan huruf vokal [o] lebih mudah untuk direpresentasikan. Selain itu, berdasarkan pengamatan peneliti, salah satu faktornya, yakni usia sehingga ia mudah untuk mengungkapkan kata [dongo] tersebut yang pada dasarnya berkonotasi negatif.

\section{SIMPULAN}

Secara umum dapat disimpukan bahwa pemerolehan bahasa yang didapatkan oleh SM dan NS secara intensif dipengaruhi oleh percakapan negatif keluarga. Dalam hal ini, tidak hanya keluarga saja atau dikatakan sebagai faktor internal yang berperan dalam pemerolehan bahasa, tetapi pengaruh faktor eksternal seperti lingungan sosial, baik itu teman-teman sebaya atau yang tidak sebaya, tetangga, dan yang lainnya.

Adapun pemerolehan bahasa yang dipengaruhi oleh percakapan negatif tersebut dikaji dalam pemerolehan vokal (fonologi). Pemerolehan vokal yang terjadi pada SM dan NS tersebut terdapat pada huruf [a], [i], [u], [e], dan [o] baik itu yang terdapat pada bagian awal, tengah, maupun, akhir kata. Akan tetapi, untuk pemerolehan vokal $[\mathrm{u}]$ hanya terdapat pada bagian tengah kata saja, sedangkan [e] hanya ada pada bagian suku terakhir kata.

Adapun pemerolehan bahasa yang pengucapannya belum sempurna terdapat pada huruf gabungan konsonan, seperti [ng]. Hal itu disebabkan oleh faktor biologis, seperti terjadi pada alat ucap yang penggunanya belum maksimal. Selain itu, faktor usia sangat mempengaruhi NS dan SM dalam pemerolehan bahasanya. Percakapan negatif tidak hanya berdampak pada pemerolehan bahasa anak saja, tetapi jika pengucapan kata berkonotasi negatif, khususnya dalam percakapan keluarga selalu diucapkan dalam konteks yang tidak relevan dengan nilai dan norma masyarakat.

Dari penelitian ini ingin disampaikan bahwa sudah sepantasnya intensitas percakapan tersebut dikurangi, sebab akan berpengaruh pada karakter anak, yakni dalam hal ini SM dan NS pada perkembangan selanjutnya. Selain itu, penulis dapat membuktikan bahwa hipotesis tabulasara sangat mempengaruhi pemerolehan bahasa anak, sebab yang ditekankan adalah faktor internal dan eksternal sangat memengaruhinya.

\section{DAFTAR PUSTAKA}

Amirul, H. dan Haryono, H. 2007. Metodologi Penelitian Pendidikan. Bandung: Pustaka Setia. Melalatoa, M.J. 2008. Ensiklopedia Suku Bangsa di Indonesia. Jakarta: CV. Eka Putra.

Nugraha, O.A. "Pemerolehan Bahasa Anak Usia 4 Tahun: Kajian Semantik Penyimpangan Tuturan Anak",dalam Jurnal.ums.ac.id/index.php/KLS, 2 (2):105-108.

Nuryani dan Putra, D.A.K. 2013. Psikolinguistik. Tangerang Selatan: Mazhab Ciputat.

Purba, J. 2015. Pengelolaan Lingkungan Sosial. Jakarta: YOI. 
Pengaruh Percakapan Negatif Keluarga terhadap Pemerolehan Bahasa Anak Usia 3-4 Tahun (Imron Maulana)

Sudaryanto. 1993. Metode dan Aneka Teknik Analisis Bahasa. Yogyakarta: Duta Wacana.

Waluja, B. 2007. Sosiologi: Menyelami Fenomena Sosial di Masyarakat. Bandung: Setia Purna Inves. 